\title{
Sharia Based Marketing Analysis Communication and Education Affiliates to Customer Satisfaction and Loyalty on Inpatient Services Unit Jakarta Islamic Hospital 2016
}

\author{
Andriyani Asmuni, Nurmaini Hasibuan \\ Public Health Studies Program, \\ Faculty of Medicine and Health, University of Muhammadiyah Jakarta \\ Jakarta, Indonesia \\ drandriyanimag@gmail.com
}

\begin{abstract}
In this era of globalization business competition becomes very sharp, both in the domestic market (national) and international market (global). The era of globalization characterized by the revolution in communication technology and information technology has resulted in tremendous changes. To win the competition, the company must be able to give satisfaction to its customers. Jakarta Islamic Hospital is a hospital that is expected by the Islamic community in Jakarta to provide sharia services such as patient expectations but in its application has not been entirely a service given based on sharia. This research type is quantitative research with cross sectional method with path analysis and consecutive sampling technique where the sample selection by specifying subjects that meet the research criteria. The study was conducted from December 2015 to January 2016. To find out the characteristics of sharia marketing which consist of Teistic, Ethical, Realistic, and Humanistic does not influence to customer satisfaction while education communication variable influences to customer satisfaction. To be able to improve the characteristics of shariabased marketing so that in the future, activities that have the characteristics of marketing can be realized and felt by the customers in real results, and can maintain and enhance the role of communication and education that exist because this variable has a significant effect To customer satisfaction as well as to customer loyalty.
\end{abstract}

Keywords-Sharia Marketing; Communication and Education; Sharia based Services; Satisfaction and Loyalty; Path Analysis

\section{INTRODUCTION}

Act number 44 Year 2009 on hospital states that the hospital is a health service institution that organizes individual health services in a plenary manner including promotive, preventive, curative and rehabilitative by providing inpatient, outpatient and emergency care services.

The hospital is also a place to conduct health efforts that is every activity to maintain and improve health and aims to realize optimal health status for the community. Health efforts are carried out with a maintenance approach, health promotion (promotive), preventive prevention, curative and curative recovery (rehabilitative) which is implemented harmoniously, integrated and sustainably.
Generally, the hospital operational unit consists of two major parts, the unit of medical activities and the unit of nonmedical activities. Grouping of these units can be presented as follows [1]: (1) medical service activities unit consisting of inpatient service unit, outpatient service unit, emergency services unit, intensive care service unit, and surgical service unit, (b) medical support units, consisting of laboratory, radiology, pharmacy, kitchen, sterilization, anesthesia, diagnostic, and medic unit, (c) non-medical support units consist of sanitation, logistics, marketing, linen and laundry, medical record, physical facility and infrastructure, mechanical and electrical unit.

Hospital health care is a service product provided by the hospital to its clients. Health services provided by hospitals are a measure of the quality of the hospital. If a hospital has managed to provide good health services to provide satisfaction to its customers, means that the hospital has a good quality, vice versa. Thus, will create a positive image of the community.

Satisfaction is the feeling of pleasure or disappointment of someone who emerges after comparing the perception or the impression of the performance (or outcome) of a product and its expectations. Satisfaction is a function of perception or impression of performance and expectations. Many companies focus on high satisfaction because customers with high satisfaction create an emotional attachment to a particular brand, not just the attachment or rational preferences. The result is high customer loyalty [2].

Loyalty is an ancient term that has traditionally been used to describe loyalty and devotion to the state, ideals, or individuals. In the business context, loyalty is used to describe the customer's willingness to subscribe to a company over the long term, by purchasing and using its goods and services repeatedly, exclusively, and voluntarily recommending the company's products to friends [2].

Specific research has been conducted in the inpatient unit by [3] on Analysis of Sharia-Based Marketing Characteristics of Inpatient Patients at Cempaka Putih Jakarta Islamic Hospital to ensure quality of service quality and satisfy according to patient's expectation. 
The survey was conducted in October 2014 with a total sample of 169 people. From the survey results obtained by customers are still not satisfied with the services provided in the outpatient section of the front building, the results of customer satisfaction survey seen from the value of honesty with what has been promised has not been implemented, whether the doctor's accuracy in timely practice and about the hospitality and suitability of fees with tariffs and facilities As well as the cleanliness of the toilet felt the patient is still less satisfied.

Sharia-based service activities should be restored to the true characteristics, religious, ethical, realistic and uphold humanistic values. The concept is currently known as shariabased services Sharia-based services in the Islamic Hospital Jakarta Cempaka Putih should have begun to be applied because the majority of customer segmentation Jakarta Cempaka Putih Islamic Hospital is a religion of Islam so that sharia services need to be realized because the sharia service is not just a Services are added sharia but there are more values on sharia services, or more services play a role in sharia and sharia play a role in service.

In this research that will be studied is the characteristics of sharia-based marketing in Outpatient of Jakarta Islamic Hospital, this is with consideration that outpatient unit is a service so that contact between customer and officer often happened when customer doing outpatient service, then officer Will inform the service to the customer either with personal guarantees or company guarantees, and when the officer provides services to the customer. It is expected that on this occasion, the service provided by the Sharia can give satisfaction to the customers. While the characteristics of sharia marketing is considered important to know the effect on customer satisfaction because when customers wait for service in outpatient polyclinics require waiting time so that the expected customers will feel comfortable and satisfied with the services provided based on sharia. If customers feel satisfied then it is expected to be able to create customer loyalty to the Jakarta Islamic Hospital in general and in outpatient in particular.

Therefore, it is necessary to conduct a research on how the influence of the characteristics of sharia-based marketing to the value of customer satisfaction in order to create customer loyalty in Outpatient of Jakarta Islamic Hospital. Customer Satisfaction and loyalty in Outpatient is very important to note that the Outpatient function as a revenue center unit in a hospital can be optimal, where the income from Outpatient Installation give a very significant contribution in a hospital.

\section{RESEARCH MethoD}

This research uses quantitative approach with cross sectional method and path analysis. The path analysis model is used to analyze the relationship pattern between the variables with the aim to know the direct and indirect effect between the exogenous variables of sharia marketing and educational communication to the endogenous variables of customer satisfaction and customer loyalty, where the variable of customer satisfaction can also function as an intervening variable. This research was conducted in December 2015 until January 2016 in Jakarta Islamic Hospital. The population in this study are customers who are waiting for service in Outpatient Polyclinic. The number of samples obtained as many as 400 questionnaires that have been filled by respondents who meet the inclusion criteria that has been at least three times outpatient treatment. Sampling technique in this research is consecutive sampling where the sample selection by specifying subjects that meet the criteria of research included in the study until a certain time, so that the number of respondents can be infested.

\section{RESULTS}

\section{A. Testing of Research Results}

Hypothesis testing that has been formulated is done by using path analysis as follows:

1. H1: Sharia Marketing (X1) Theistic, Ethical, Realistic, umanistic effect on (Y) customer satisfaction.

2. H2: Sharia, Theistic, Ethical, Realistic, Humanistic (X1) Marketing influences (Z) customer loyalty.

3. H3: Communication, education (X2) affects (Y) customer satisfaction.

4. H4: Communication, education affects (Z) customer loyalty.

5. H5: Customer satisfaction (Y) effect on (Z) customer loyalty.

TABLE I. STANDARDIZED COEFFICIENT OF DIRECT EFFECT

\begin{tabular}{|c|c|c|c|}
\hline & & & Estimate \\
\hline Customer Satisfaction & $\leftarrow$ & Sharia Marketing & -0.052 \\
\hline Customer Satisfaction & $\leftarrow$ & $\begin{array}{c}\text { Communication and } \\
\text { Education }\end{array}$ & 0.869 \\
\hline Customer Loyalty & $\leftarrow$ & Customer Satisfaction & 0.345 \\
\hline Customer Loyalty & $\leftarrow$ & Sharia Marketing & -0.558 \\
\hline Customer Loyalty & $\leftarrow$ & $\begin{array}{c}\text { Communication and } \\
\text { Education }\end{array}$ & 0.958 \\
\hline
\end{tabular}

TABLE II. STANDARDIZED INDIRECT EFFECT COEFFICIENT

\begin{tabular}{|c|c|c|c|c|}
\hline & $\begin{array}{r}\text { Communication } \\
\text { and Education }\end{array}$ & $\begin{array}{r}\text { Shari } \\
\text { Marketin }\end{array}$ & $\begin{array}{l}\text { Customer } \\
\text { Satisfaction }\end{array}$ & $\begin{array}{r}\text { Customer } \\
\text { Loyalty }\end{array}$ \\
\hline $\begin{array}{l}\text { Customer } \\
\text { Satisfaction }\end{array}$ & 0.000 & 0.000 & 0.000 & 0.000 \\
\hline $\begin{array}{l}\text { Customer } \\
\text { Loyalty }\end{array}$ & 0.299 & -0.018 & 0.000 & 0.000 \\
\hline
\end{tabular}


TABLE III. SQUARED MULTIPLE CORRELATIONS: (GROUP NUMBER 1DEFAULT MODEL)

\begin{tabular}{|c|c|c|c|}
\hline & & & Estimate \\
\hline Customer Satisfaction & & & 0.672 \\
\hline Customer Loyalty & & & 0.717 \\
\hline
\end{tabular}

The first form of equation is

$$
\mathrm{Y}=p y x_{1} \mathrm{X}_{1}+p y x_{2} \mathrm{X}_{2}+p y \varepsilon_{1}
$$

Customer Satisfaction $=-0.052$ sharia marketing +0.867 communication and Education $\mathrm{R}^{2}$ obtained from this equation is 0.672 .

This means that sharia marketing and communication and education can explain the variables of customer satisfaction of $67.2 \%$ while the rest of $32.8 \%$ can be explained by other variables not examined in this study.

The second form of equation is

$$
\mathrm{Z}=p z x_{1} \mathrm{X}_{1}+p z x_{2} \mathrm{X}_{2}+p z y \mathrm{Y}+\mathrm{pz} \varepsilon_{2}
$$

Customer loyalty $=-0,558$ sharia marketing $+0,958$ communication and education $+0,345$ customer satisfaction $\mathrm{R}^{2}$ obtained from this equation is 0.717 .

This means that sharia marketing, communication and education and customer satisfaction can explain the variable of customer loyalty equal to $71.7 \%$ while the rest equal to $28,3 \%$ can be explained by other variable not examined in this research.

\section{The form of equation indirect effect is}

Customer loyalty $=-0.018$ sharia marketing through Customer satisfaction +0.299 communication and education through customer satisfaction.

\section{DISCUSSION}

\section{A. Hfypothesis Testing}

Hypothesis test criteria are as follows:

a) if $\mathrm{p}$-value $<0.05$, then $\mathrm{H} 0$ is rejected.

b) if p-value is $\geq 0.05$, then $\mathrm{H} 0$ fails to be rejected.

\section{Hypothesis 1}

The null hypothesis ( $\mathrm{H} 0)$ and the alternative hypothesis (Ha) are as follows:

$\mathrm{H}_{01}$ : The characteristics of sharia marketing that consist of Theistic, Ethical, Realistic, and Humanistic (X1) does not affect $Y$ (customer satisfaction).

$\mathrm{H}_{\mathrm{a} 1}$ : The characteristics of sharia marketing that consists of Theistic, Ethical, Realistic, and Humanistic (X1) effect on Y (customer satisfaction).

\begin{tabular}{|c|c|c|c|c|}
\hline Hypothesis & Path & $\begin{array}{c}\text { Standardized } \\
\text { Coefficient }\end{array}$ & $\begin{array}{c}P- \\
\text { Value }\end{array}$ & Keputusan \\
\hline $\mathbf{H}_{1}$ & $\begin{array}{c}\text { Characteristics } \\
\text { of Sharia } \\
\text { Marketing } \\
\rightarrow \text { Customer } \\
\text { Satisfication }\end{array}$ & -0.052 & 0.862 & $\mathrm{H}_{01}$ accepted \\
\hline $\mathbf{H}_{2}$ & $\begin{array}{l}\text { Communication } \\
\text { and Education } \\
\rightarrow \text { Customer } \\
\text { Satisfication }\end{array}$ & 0.869 & 0.005 & $\mathrm{H}_{02}$ rejected \\
\hline $\mathbf{H}_{3}$ & $\begin{array}{c}\text { Characteristics } \\
\text { of Sharia } \\
\text { Marketing } \\
\rightarrow \text { Customer } \\
\text { Loyalty }\end{array}$ & -0.558 & 0.107 & $\mathrm{H}_{03}$ accepted \\
\hline $\mathbf{H}_{4}$ & $\begin{array}{l}\text { Communication } \\
\text { and Education } \\
\rightarrow \text { Customer } \\
\text { Loyalty }\end{array}$ & 0.958 & 0.008 & $\mathrm{H}_{04}$ rejected \\
\hline $\mathbf{H}_{5}$ & $\begin{array}{c}\text { Customer } \\
\text { Satisfication } \rightarrow \\
\text { Customer } \\
\text { Loyalty }\end{array}$ & 0.345 & 0.000 & $\mathbf{H}_{05}$ rejected \\
\hline
\end{tabular}

TABLE IV. HYPOTHESIS TESTING RESULTS

Source: Data is processed with IBM SPSS AMOS v.22.0

In the test of hypothesis 1 , p-value $0.862>$ alpha 0.05 , then $\mathrm{H}_{01}$ accepted (H1 cannot be supported), this means that the characteristics of sharia-based marketing that consists of Theistic, Ethical, Realistic, and Humanistic (X1) has no effect on (customer satisfaction). Variable Characteristics of Sharia Marketing have direct effect coefficient $(\beta 1)=-0,052$ and have negative value, it can be concluded that Characteristic of Sharia Marketing have negative relation and insignificant with Customer Satisfaction. The negative value of $\beta$ indicates that the variable $\mathrm{X} 1$ has a reversed relationship with Y. In other words the higher Sharia Marketing Characteristics will make Customer Satisfaction is lower, and the effect is not statistically significant.

A study conducted by Nucivera (2010) based on statistical results on hypothesis testing $t$ arithmetic found that Humanistic does not affect the characteristics of sharia marketing that impact on satisfaction, but based on the results of in depth interviews in this study humanistic has a relationship to the characteristics of sharia marketing [3]. This should be consistent with Kartajaya and Sula (2008) that the other features of sharia marketing are universal humanistic, namely that sharia is created for human beings to be elevated, their humanity maintained and nurtured. Islamic Sharia is created for human beings according to their capacity, regardless of race, color, nationality and status [4]. Another research conducted by Helvrizky Kaniza (2011) shows that the correlation between the implementation of sharia marketing management with customer satisfaction has a relationship of 
0.58 can be conclude its have a moderate relationship. Partially based on t test states that the Theistic (rabbaniyyah) variable has a positive and significant effect on customer satisfaction of BPD Sharia Branch Yogyakarta while Ethis (akhlaqiyyah) and Realistic variable (al-waqi'iyyah) have no significant effect on customer satisfaction of BPD Sharia.

There is a differences in statistical results based on experience and observation of researchers at Jakarta Islamic Hospital caused by some doctors when explaining the disease to the patients with language that is less easily understood. Basically doctors and nurses of Jakarta Islamic Hospital already trying to serve in accordance with Islamic sharia principles as already exist in the application of Islamic behavior there are still some shortcomings in the implementation.

\section{Hypothesis 2}

The null hypothesis (H0) and the alternative hypothesis (Ha) are as follows:

$\mathrm{H}_{02}$ : Communication and Education (X2) has no effect on $\mathrm{Y}$ (customer satisfaction).

$\mathrm{H}_{\mathrm{a} 2}$ : Communication and Education (X2) affect $\mathrm{Y}$ (customer satisfaction).

In test of hypothesis 2, p-value 0.005 <alpha 0.05 , then $\mathrm{H}_{02}$ is rejected (H2 can be supported), this means Communication and Education (X2) affect $\mathrm{Y}$ (customer satisfaction). Coefficient of direct effect $(\beta 2)=0.869$ and have positive value, it can be concluded that Communication and Education have positive and significant relation with Customer Satisfaction. The positive $\beta$ values indicate the higher Communication and Education will also make the Customer Satisfaction higher, and the influence is statistically significant.

Silverman (1998) explains that effective communication does not stop until the giver completes the point [5]. New communication can be said to be complete when the speaker gets feedback from the recipient assuring him that the purpose of communication is achieved (the message recipient understands as expected). Another study conducted by Sofyan et al, states that the quality of service variables affect customer satisfaction Star Clean Car Wash Semarang of 53.3\% [6].

\section{Hypothesis 3}

The null hypothesis ( $\mathrm{H} 0)$ and the alternative hypothesis (Ha) are as follows:

$\mathrm{H}_{03}$ : The characteristics of sharia marketing that consist of Theistic, Ethical, Realistic, and Humanistic (X1) have no effect on Z (customer loyalty).

$\mathrm{H}_{\mathrm{a} 3}$ : The characteristics of sharia marketing that consists of Theistic, Ethical, Realistic, and Humanistic (X1) effect on Z (customer loyalty).

In the test of hypothesis 3 , the value of p-value $0.107>$ alpha 0.05 , then $\mathrm{H}_{03}$ accepted (H3 cannot be supported), this means that the characteristics of Islamic marketing that consists of Theistic, Ethical, Realistic, and Humanistic (X1) have no effect on (customer loyalty). Sharia Characteristic variables have direct effect coefficient $(\beta 3)=-0,558$ and have negative value, it can be concluded that the higher Sharia Marketing Characteristics will make Customer Loyalty is lower, and the influence is not statistically significant.

However, the results of this study is different from the theory and research results that have been done previously as described above. Some things that can explain the results of this study that sharia based services in Outpatient Jakarta Islam Hospital no significant effect on customer loyalty because Jakarta Islamic Hospital is a hospital type B with market share is a middle to lower social class and most of which is approximately $65 \%$ are patients with BPJS health insurance. The condition of the customer with the lower middle social class causes the customer service preference not to the sharia based service, but they expect the doctor's accuracy, also the education communication provided by the doctor.

Nevertheless, although sharia-based service variables do not statistically have direct and significant influence on customer loyalty, the researcher assumes that this variable is important to be considered for reasons if sharia-based services can be improved in terms of hospitality, communicative, speed, accuracy and decency and the others variables, it will be able to further increase customer satisfaction that can impact on customer loyalty.

This is in line with the opinion according to Irawan (2004) states the factors that affect a product or service are as follows: (a) Value (price and quality; (b) Image (both of the personality it possesses and the reputation of the company; (c) Comfort and convenience in service; (d) Satisfaction felt by consumers, (e) Service, with good service quality can influence consumer loyalty [7].

According by Frederick F Reicheld, if consumers have a full desire to buy a certain product/service again, when consumers need these products/services, that is called loyalty. Consumers who are satisfied with the goods or services they consume will have a tendency to buy again from the same manufacturer [6]. Therefore, the activities of sharia based services must be restored to the actual characteristics, namely religious, ethical, realistic and uphold humanistic values to be effective in increasing customer loyalty.

\section{Hypothesis 4}

The null hypothesis (H0) and the alternative hypothesis (Ha) are as follows:

$\mathrm{H}_{04}$ : Communication and Education (X2) has no effect on $\mathrm{Z}$ (customer loyalty).

$\mathrm{H}_{\mathrm{a} 4}$ : Communication and Education (X2) effect on $\mathrm{Z}$ (customer loyalty).

In testing hypothesis 4, p-value $0,008<$ alpha 0,05 , then $\mathrm{H}_{04}$ is rejected (H4 can be supported), this means Communication and Education (X2) affect to $\mathrm{Z}$ (customer loyalty). Communication and Education Variables have direct effect coefficient $(\beta 4)=0,958$ and have positive value, it can be concluded that higher Communication and Education will make Customer Loyalty higher, and influence is statistically significant. 
According by Stephen P. Robbins (2006), an estimated 5$20 \%$ in the population suffers from anxiety or nervous in communicating. Often people get scared when speaking in public. They experience unnecessary tension and anxiety in both oral and written communication. In the observation of researchers, Jakarta Islamic Hospital has made patients comfortable in communicating so that this variable has a significant effect.

\section{Hypothesis 5}

The null hypothesis ( $\mathrm{H} 0)$ and the alternative hypothesis (Ha) are as follow:

$\mathrm{H}_{05}$ : Customer Satisfaction (Y) has no effect on $\mathrm{Z}$ (customer loyalty).

$\mathrm{H}_{\mathrm{a} 5}$ : Customer Satisfaction (Y) effect on Z (customer loyalty).

In testing hypothesis 5 , p-value 0.000 <alpha 0.05 , then $\mathrm{H}_{05}$ is rejected (H5 can be supported), this means that Customer Satisfaction (Y) influence $\mathrm{Z}$ (customer loyalty). Customer Satisfaction Variables have direct effect coefficient $(\beta 5)=$ 0,345 and have positive value, it can be concluded that Higher Customer Satisfaction will make higher Customer Loyalty, and its influence is statistically significant.

Therefore the results of this study in accordance with the theory that states to win the competition, the company must be able to provide satisfaction to its customers. Customers have to be satisfied, because if they are not satisfied they will be leaving the company and becoming competitor customers, this will lead to a decrease in sales and in turn will make lower profits and even losses. So that, the leadership of the company should try to measure the level of customer satisfaction to immediately know what attributes of a product that can make customers dissatisfied [8].

The findings of this study in accordance with the results of research Fajarriani (2013) that the satisfaction variable has a positive and significant impact on customer loyalty Brayat Minulya Sirakarta Hospital [9]. The results of this study are also in line with research conducted by Sawitri (2013) that customer satisfaction has a positive and significant influence on customer loyalty, with coefficient 0.461 . This means that the higher level of customer satisfaction Tegal Sari Accommodation makes the customer loyalty is increasing, vice versa.

\section{CONCLUSION}

Based on the results of the discussion using the path analysis obtained the following conclusions (1) The relationship of the characteristics of sharia marketing to customer satisfaction is negative with probability of -0.52 , while the result of hypothesis test 1 is known that p-value of $0.862>0.05$, so it can be concluded Shariah-based marketing characteristics consisting of Theistic, Ethical, Realistic, And Humanistic (X1) does not affect Y (customer satisfaction). (2) The relationship between the characteristics of shariah marketing to customer loyalty is negative with the value of the path coefficient equal to 0.558 , and the results of hypothesis testing is Ho accepted, which means the characteristics of shariah marketing does not affect customer loyalty. (3) The relationship between communication and education to customer satisfaction is positive with the value of probability path coefficient equal to 0.86 , while result of test of hypothesis 2 known that p-value equal to $0.005<0.05$, so it concluded Communication and Education (X2) influence to Y (satisfaction customer). (4) The correlation between communication and education to customer loyalty is positive with path coefficient value 0.958 , and result of hypothesis test 4 is known that p-value equal to $0.008<0.05$, so concluded Communication and Education (X2) influence to Z (customer loyalty). (5) The relationship between customer satisfaction with customer loyalty is positive with path coefficient value of 0.345 , while the result of hypothesis test 5 is known that $\mathrm{p}$ value is $0.000<0.05$, so it is concluded that customer satisfaction (Y) influences $\mathrm{Z}$ (customer loyalty).

From the analysis of path analysis, the variable characteristics of sharia-based marketing (X1) to customer satisfaction $(\mathrm{Y})$ and to customer loyalty $(\mathrm{Z})$ is not accepted and no positive effect. Meanwhile, the influence of Communication and Education (X2) variables on customer loyalty has the greatest influence compared to other variables. Thus the variable of customer satisfaction $(\mathrm{Y})$ is not effective as an intermediary to generate customer loyalty.

Based on the above conclusions, then can be put forward some suggestions that would be useful for Jakarta Islamic Hospital Cempaka Putih, namely to be able to improve the characteristics of sharia-based marketing so that in the future, activities that have the characteristics of marketing can be realized and felt by the customers in real results. They should be maintain and improve the role of communication and education that exist because this variable has a significant effect on customer satisfaction as well as on customer loyalty.

To optimize customer loyalty should be pursued the things that can fill up customer expectations so that customer satisfaction increases, because customers who are satisfied with the goods or services will have a tendency to buy from the same manufacturer again. For further research can analyze the other characteristics than those already researched and the comparison with other similar hospitals to see the variation of existing data. In providing better patient services, to improve the application of existing Islamic behavior, so that all health providers in Jakarta Islamic Hospital become more sharia in every action taken, and evaluate the sharia based services for hospitals to have an accurate data on sharia based services that have been executed so far whether it is right on target or not.

\section{REFERENCES}

[1] Adisasmito, Wiku. Sistem Manajemen Rumah Sakit. Jakarta: PT. Raja. GrafindoPersada, 2009.

[2] Lovelock, Christopher H dan Lauren K. Wright, Manajemen Pemasaran Jasa. Alih Bahasa :Agus Widyantoro, Cetakan Kedua, Jakarta : PT. INDEKS, 2007.

[3] Nucivera, Junike, "Analisis Karakteristik Pemasaran Berbasis Syariah pada Pasien Rawat Inap di RS Islam Jakarta Cempaka Putih Tahun 2010” Depok : Program Pascasarjana Fakultas Kesehatan Masyarakat, 
[4] Hermawan, Kartajaya, Muhammad Syakir Sula, Syariah Marketing. Cetakan Keempat. Bandung : PT. Mizan Pustaka, 2008.

[5] Silverman, J., Kurt, S, Teaching and Learning Communication Skills in Medicine. Great Britain : Radcliffe Medical Press, 1998.

[6] Sofyan, Indra Lutfi, Ari Pradhanawati, Hari Susanta Nugrah, "Pengaruh Fasilitas dan Kualitas Pelayanan terhadap Loyalitas, melalui Kepuasan Konsumen Sebagai Variabel Intervening pada Star Clean Car Wash Semarang Diponegoro" Journal of Social and Politic Page 1 - 12, 2013.

[7] Irawan, Handi. Kepuasan Pelangggan. Jakarta : PT Gramedia Pustaka, (2004).

[8] Sutojo, Membangun Citra Perusahaan. Jakarta : PT Damar Mulia Pustaka, 2003.

[9] Fajarriani, Pengaruh Physical Support, Contact Personnel, Citra, Kepercayaan terhadap Kepuasan dan Loyaliatas Pelanggan Rumah Sakit Brayat Minulya Surakarta. [Tesis]. Surakarta: Program Pascasarjana STIE Adhi Unggul Bhirawa, 2013. 